IZA DP No. 5220

Distributional Consequences of Labor Demand Adjustments to a Downturn: A Model-Based Approach with Application to Germany 2008-09

Olivier Bargain

Herwig Immervoll

Andreas Peichl

Sebastian Siegloch

September 2010 


\title{
Distributional Consequences of Labor Demand Adjustments to a Downturn: A Model-Based Approach with Application to Germany 2008-09
}

\author{
Olivier Bargain \\ UC Dublin, ESRI, Geary Institute, \\ CHILD and IZA \\ Herwig Immervoll \\ OECD, ISER and IZA \\ Andreas Peichl \\ IZA, University of Cologne, ISER and CESifo \\ Sebastian Siegloch \\ IZA and University of Cologne \\ Discussion Paper No. 5220 \\ September 2010 \\ IZA \\ P.O. Box 7240 \\ 53072 Bonn \\ Germany \\ Phone: +49-228-3894-0 \\ Fax: +49-228-3894-180 \\ E-mail: iza@iza.org
}

Any opinions expressed here are those of the author(s) and not those of IZA. Research published in this series may include views on policy, but the institute itself takes no institutional policy positions.

The Institute for the Study of Labor (IZA) in Bonn is a local and virtual international research center and a place of communication between science, politics and business. IZA is an independent nonprofit organization supported by Deutsche Post Foundation. The center is associated with the University of Bonn and offers a stimulating research environment through its international network, workshops and conferences, data service, project support, research visits and doctoral program. IZA engages in (i) original and internationally competitive research in all fields of labor economics, (ii) development of policy concepts, and (iii) dissemination of research results and concepts to the interested public.

IZA Discussion Papers often represent preliminary work and are circulated to encourage discussion. Citation of such a paper should account for its provisional character. A revised version may be available directly from the author. 
IZA Discussion Paper No. 5220

September 2010

\title{
ABSTRACT \\ Distributional Consequences of Labor Demand Adjustments to a Downturn: A Model-Based Approach with Application to Germany 2008-09*
}

\begin{abstract}
Macro-level changes can have substantial effects on the distribution of resources at the household level. While it is possible to speculate about which groups are likely to be hardesthit, detailed distributional studies are still largely backward-looking. This paper suggests a straightforward approach to gauge the distributional and fiscal implications of large output changes at an early stage. We illustrate the method with an evaluation of the impact of the 2008-2009 crisis in Germany. We take as a starting point a very detailed administrative matched employer-employee dataset to estimate labor demand and predict the effects of output shocks at a disaggregated level. The predicted employment effects are then transposed to household-level microdata, in order to analyze the incidence of rising unemployment and reduced working hours on poverty and inequality. We focus on two alternative scenarios of the labor demand adjustment process, one based on reductions in hours (intensive margin) and close to the German experience, and the other assuming extensive margin adjustments that take place through layoffs (close to the US situation). Our results suggest that the distributional and fiscal consequences are less severe when labor demand reacts along the intensive margin.
\end{abstract}

JEL Classification: D58, J23, H24, H60

Keywords: labor demand, tax-benefit system, crisis, income distribution

Corresponding author:

Andreas Peichl

IZA

P.O. Box 7240

53072 Bonn

Germany

E-Mail: peichl@iza.org

\footnotetext{
* We thank Tim Callan, Daniel Hamermesh and John Martin for valuable comments. Usual disclaimers apply.
} 


\section{Introduction}

The 2008-2009 economic crisis has led to a broad discussion, both in public and academia, about which policy might be most effective at mitigating the adverse labor-market and welfare consequences of the downturn. While a large number of policy initiatives has quickly followed the onset of the economic slump, policy efforts to minimize welfare losses are seriously hampered by how little is known about the distribution of changes in employment and incomes, and about the capacity of existing redistribution systems to soften the negative impacts of job and earnings losses. In order to assess the real-time consequences of the downturn, policymakers would need real-time microdata to obtain a precise picture of the distributional distortions. While it is possible to speculate about which groups are likely to be hardest-hit, detailed distributional studies are usually not available until the crisis is long over and important policy decisions have already been made.

In this paper, we develop a straightforward approach to gauge the distributional and fiscal implications of large output changes at an early stage. Rather than imputing income changes using reweighting techniques or similar procedures, we identify demand-side adjustments using an estimated labor demand model, and then feed them to household data, in order to assess their distributional consequences. We illustrate the method with an evaluation of the impact of the 2008-2009 crisis in Germany. More precisely, we first estimate a labor demand model based on twelve years of high-quality, micro-level administrative employer-employee data (LIAB). The model is used to predict the employment effects of output shocks observed during the current labor market downturn at a disaggregated level (by industry and for labor inputs detailed by age, skill and contract type). In a second step, we transpose the predicted labor-market changes to household-level microdata commonly used for distributional analyses (the German Socio-Economic Panel, GSOEP). Using this combined approach, we can analyze the first-round consequences of the recession for gross income changes at the household level. Employing tax-benefit simulation, we can also assess the income cushioning effects of the welfare system and quantify aggregate fiscal effects.

While the demand model captures total labor demand adjustment reasonably well, nothing can be inferred about the precise margin of adjustment. Yet it is likely that the type of adjustment matters for the distributional implications of the labor-market downturn. Therefore we suggest two scenarios for translating labor-demand reactions to earnings losses at the household level. The first polar case allows for adjustments at the intensive margin only (adjusting working hours per employee rather than staff levels). We will refer to this as the intensive scenario. The second polar case (extensive 
scenario) shows what happens if the same overall adjustments in total working hours occur exclusively via layoffs (and hires). The two polar cases are stylized and intended to show the main links between margins of adjustment and distributional outcomes. Yet the first case closely corresponds to the German situation where labor-market adjustments to a sharp drop in GDP occurred almost exclusively along the intensive margin. By contrast, other countries, including the United States, saw major layoffs and substantial increases in unemployment rates (OECD (2010)). Hence our extensive scenario can be interpreted as a counterfactual of what would have happened if Germany had experienced more of a US-style labor market response to the crisis.

Our results show that the margin of adjustments indeed matters. Given the likely pattern of job losses among different groups of workers, adjustments at the extensive margin result in a sizable widening of the income distribution, increasing inequality and driving up the number of poor people by more than ten percent. In the intensive scenario, poverty headcounts rise by under four percent, while most inequality measures are predicted to change little. Importantly, adjustments at the intensive margin are also preferable from a fiscal point of view, at least in the short-term.

To the best of our knowledge, this is the first empirical study linking output changes to distributional and fiscal consequences using a detailed micro model of labor-demand responses. The approach is conceptually related to the literature on linking micro and macro models (see, e.g., Bourguignon et al. (2003), or Peichl (2009) for a survey). ${ }^{1}$ In particular, it is closer to the "top-down" approach which aims to approximate the effect of macro changes on income distribution. However, in our study, the macro level output shocks are not derived from a stylized CGE-type of model but correspond directly to the observed changes per industry for the years 2008-2009. ${ }^{2}$ Hence, we ignore longer-term changes in prices and wages which is justified in the German case since wage adjustments were not a primary channel for reducing labor costs during the downturn (Collective Agreement Archive (2009), Bellmann \& Gerner (2010)). Instead we focus on short-term labor demand adjustments, which are the most immediate driver of household income losses during a labor-market downturn. Our approach puts the emphasis on a model that accounts for the heterogeneity of adjustment patterns needed for distributional analyses.

The remainder of the paper is structured as follows. Section 2 briefly summarizes the labor-market changes in Germany since the onset of the crisis and contrasts them with the

\footnotetext{
${ }^{1}$ For distributional analyses based on these techniques and specific applications to economic crises, see Bourguignon et al. (2008), Herault (2010), Ahmed \& O'Donoghue (2010), Ferreira et al. (2008) and Robilliard et al. (2008).

${ }^{2}$ Note that the method that we suggest here is more general as it does not depend on observed data on actual output changes. It can also be applied as a tool for ex ante policy response analyses if one uses projections (of output changes) in order to analyze forward-looking counterfactual scenarios.
} 
US experience. In Section 3, we lay out our empirical approach, present the data and the estimation of the labor demand model. In Section 4, we predict the first-round effect of output shocks on the demand for different labor inputs, compare them to observed labormarket trends, and analyze the distributional consequences of labor market adjustments at the household level. Finally, we derive and discuss the fiscal consequences of workinghour reductions versus layoffs. Section 5 concludes.

\section{The German Labor Market during the Crisis}

The German labor market performance has received considerable attention since the onset of the 2008-2009 economic crisis. Figure 1 illustrates the unique adjustment patterns in Germany by contrasting the evolution of output and employment against those observed in the United States.

During the recent economic crisis, Germany suffered particularly sizable output losses of almost seven percent since GDP peaked in 2008Q1. Yet, employment levels as shown by the black solid line remained practically unchanged, suggesting an unusually low Okun's coefficient value. Nonetheless, Figure 1 shows that the crisis did have a significant effect on the German labor market. Up until 2009Q2, hours worked per employee (as well as total working hours in the economy) declined by four percent (black dashed line). Hence, on aggregate, the adjustments materialized exclusively at the intensive margin (the difference between the solid and the dashed lines). In contrast to the German situation, US employment dropped by almost five percent despite a smaller drop in GDP (grey solid line). Most of the adjustment happened along the extensive margin whereas working-hour reductions along the intensive margin accounted for only around one third of the drop in total hours worked (grey dashed line).

The specific adjustment witnessed in Figure 1 is in part the result of possibilities and constraints induced by labor market conditions and institutions (see, e.g., Möller (2010), Eichhorst et al. (2010), OECD (2010)). In the German context, the government-supported short-time working scheme (the Kurzarbeitergeld) has tended to receive most of the attention. Yet, while a substantial part (around 25 percent) of working-time reductions during the crisis to date can indeed be directly attributed to this programme, other factors were more important on aggregate. The biggest reductions, accounting for more than one third of recorded changes in total hours worked, were due to opening clauses in collective agreements, which provide for temporary reductions in weekly working hours (and earnings), or to so-called "pacts for employment and competitiveness" between employers and employees. In addition, working-time accounts or "time banks", as well as substantially reduced overtime, account for about 20 percent each (Bellmann et al. (2008)). 
Figure 1: Labor-market Adjustments: Germany vs. US

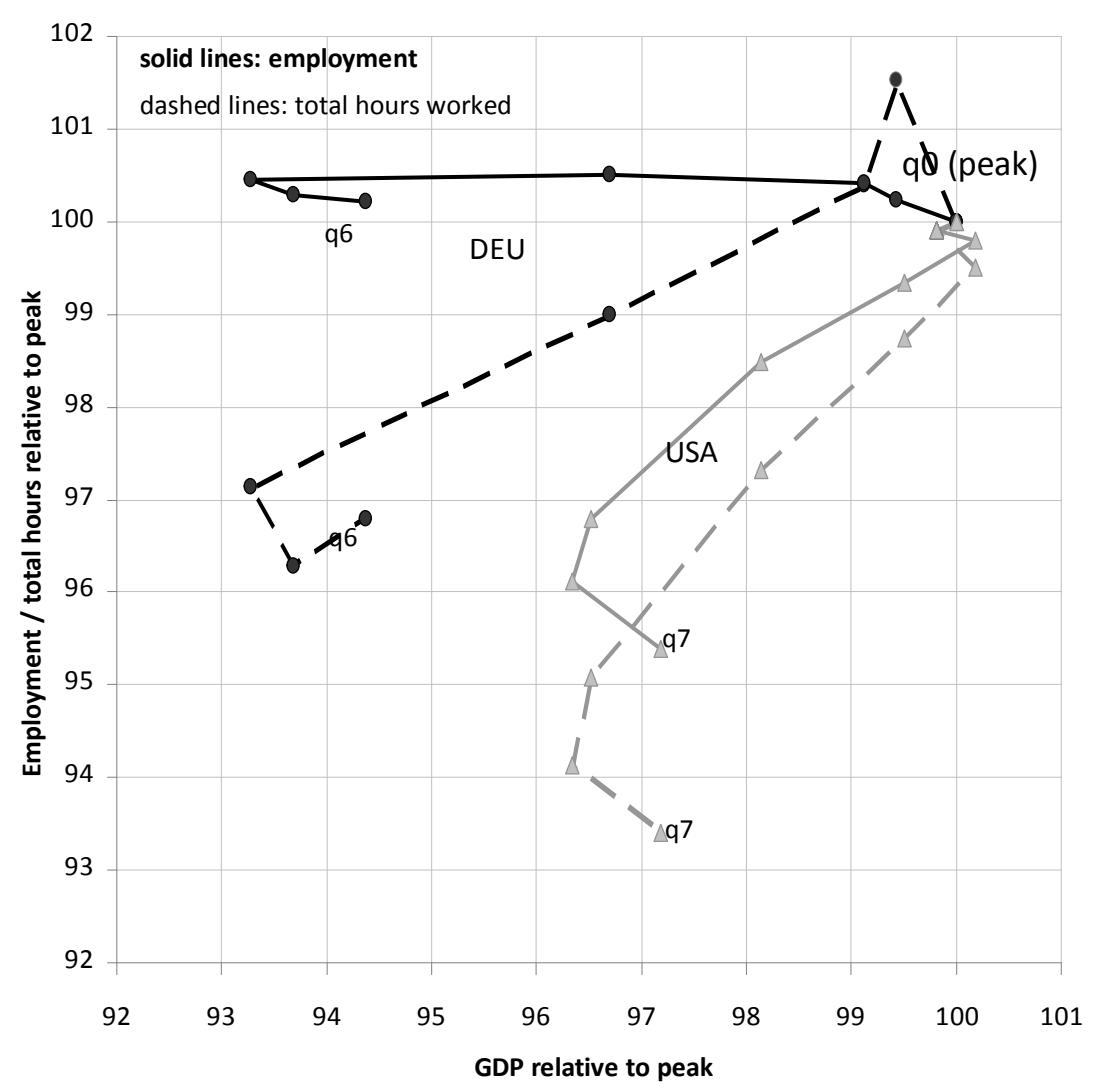

Source: OECD National Accounts database and calculations based on national and Eurostat labor market statistics. Notes: Q0 is the quarter when GDP peaked (2007Q4 for US and 2008Q1 for Germany) and each data point refers to consecutive quarters since then.

In our analysis, we set up a framework which is general enough to comprise both the intensive and extensive margin. This allows us to simulate two polar scenarios of adjustment, which come close to the contrasted situations depicted in Figure 1. This will be described in the next Section.

\section{Empirical Approach}

To study the short-term effects of a large output shock on employment and income, we derive the likely patterns of demand-side adjustments using our own labor demand estimations. We assume a "right-to-manage" setting, with employment and hours chosen by the firm. Wages are fixed in the short term and labor inputs are the only margins of adjustment for firms (capital is constant). The labor demand model is estimated on 
matched employer-employee data for Germany. In a second step, the demand-side model is linked to household-level data and tax/benefit simulations are conducted in order to derive the distributional consequences. Before proceeding with the distributional analysis in Section 4, this section presents details on data sources and labor demand estimations.

\subsection{Data}

The demand model relies on a high-quality linked employer-employee dataset (LIAB) from the Institute for Employment Research (IAB) in Nuremberg, Germany, (see Alda et al. (2005) for more information on the dataset and von Wachter \& Bender (2006) for a recent application). The firm component of the LIAB is the IAB Establishment Panel (cf. Kölling (2000). The term "establishment" refers to the fact that the observation unit is the individual plant, not the firm; there can be several plants per company. The Establishment Panel is a representative stratified random sample containing annual information on establishment structures and personnel decisions for years 1993 onwards. It includes establishments with at least one worker for whom social contributions were paid, covering 16 industries and establishments from both West and East Germany. Information on employment levels and changes, the structure of staff qualification, export, investment and technological status as well as industry affiliation and output are used.

The employee data corresponds to the employment statistics of the German Federal Employment Agency (Bundesagentur für Arbeit), drawn from official records - the German employment register - which comprises all employees paying social security taxes or receiving unemployment benefits (see, e.g., Bender et al. (2000)). The dataset covers about 80 percent of German employees in the private sector. The entire public sector is excluded as civil servants are not observed in the social security data. Information recorded in the data include employees' histories on daily wages, age, seniority, schooling, training, occupation, employment type (full-time, part-time or irregular employment), industry and region.

Data from the employee history are linked with the establishment sample year-by-year using a plant identifier. Since the unified sample for East and West Germany exists only since 1996, we focus on the period 1996-2007. We select establishments with at least 10 employees, in order to be able to identify substitution patterns between different types of workers. In total, our resulting sample consists of 37, 958 establishment-year observations. The number of establishment-years is 19,520 in Manufacturing (51 percent of the total), 5, 035 in Construction (13 percent), 1, 847 in Transport and Communications (5 percent), 10, 956 in Services (29 percent) and 600 in Financial Services (2 percent).

For the distributional analysis, we use the German Socio-Economic Panel (GSOEP), a 
well-known household survey. The GSOEP is a representative survey of the entire German population with about 25,000 sample individuals living in more than 10,000 households per cross-section (East Germany was added in 1990) (see Wagner et al. (2007)). For the present paper, we utilize information on labor-market status, gross wage, job type, benefits, industry, working time, household composition, age, education levels and housing costs. We use the 2008 wave, containing labor market information, in particular hours worked and wages, for the year $2007 .^{3}$ In order to make information consistent with the distributional analysis (January 2009), we use a static ageing technique which allows us to control for changes in global structural variables as well as income adjustments that differentiate by income components (see Gupta \& Kapur (2000)). We restrict the sample to the same industries we employ in the LIAB, but include the unemployed. On the whole, this gives us 5,532 households and 9,218 persons. To calculate net incomes and fiscal effects, we link the data to the tax and benefit simulation model of the Institute for the Study of Labor, IZA $\Psi$ MOD, which incorporates all important features of the German tax and transfer system (see Peichl et al. (2010)).

\subsection{Labor Demand Model}

We estimate a structural labor demand model on the LIAB data. For our purposes, it is essential to adopt a micro rather than a macro approach mainly for two reasons. Firstly, the explicit goal of our contribution is to assess the consequences of output changes on the demand for narrowly defined groups of workers. This implies that we have to account for substitutions patterns between different labor inputs at the firm level. Secondly, macro models on labor demand produce unbiased results only under quite restrictive assumptions with regard to employment adjustments (see Bresson et al. (1992)).

Following standard practice, we adopt the dual approach by assuming a constant output, specifying a cost function and using Shephard's lemma to derive the labor demand functions (Hamermesh (1986, 1993) and Bond \& Van Reenen (2007)). We opt for a Generalized Leontief specification as proposed by Diewert (1971), which is a linear secondorder approximation to any arbitrary cost function. Importantly, it does not restrict the substitution elasticities of input factors. We follow the concrete specification by Diewert \& Wales (1987) and take a short-term perspective, assuming capital to be fixed (or perfectly separable from labor inputs). We also allow for non-constant returns to scale, which is important in the context of our study, since the output elasticities are not restricted to equal unity.

For a given firm, there are $i=1, \ldots I$ labor inputs corresponding to the cells we define

\footnotetext{
${ }^{3}$ As explained in the introduction, it is precisely the lack of rapid microdata production that justifies our approach. For instance, the GSOEP data for year 2008 are becoming available at the end of 2010.
} 
below. We ignore firm and time indices to clarify notations. We write $C$, the short-term labor costs of a firm, as follows:

$$
C=\sum_{i} \alpha_{i} w_{i}+\sum_{i} \sum_{j} \alpha_{i j} w_{j}^{0.5} w_{j}^{0.5} Y+\sum_{i}\left(\beta_{Y Y i} w_{i}\right) Y^{2}
$$

with $Y$ and $w_{i}$ the firm-specific output and the wage of labor group $i$, respectively. The symmetry condition $\alpha_{i j}=\alpha_{j i}, \forall i, j$, is the only restriction imposed on the coefficients. Differentiating $C$ with respect to wages $w_{i}$ yields the factor demands $X_{i}$ or, dividing by $Y$, the input-output ratio:

$$
X_{i} / Y=\alpha_{i i}+\sum_{j \neq i} \alpha_{i j}\left(\frac{w_{j}}{w_{i}}\right)^{0.5}+\alpha_{i} \frac{1}{Y}++\beta_{Y Y i} Y
$$

which is the basis of our labor demand estimation. Since we are analyzing the comparativestatic effect of output shocks, our main measure of interest is the output elasticity of input (labor) demand, which is written as:

$$
\epsilon_{i Y}=\frac{\partial X_{i}}{\partial Y} \frac{Y}{X_{i}}=1-\frac{\alpha_{i}}{X_{i}}
$$

\subsection{Estimation}

The detailed administrative data allow us to distinguish $I=12$ labor inputs per industry. We differentiate between two skill/education levels, three age groups and two categories of employment contract. Skilled workers hold a university, polytechnical, or college degree or have completed vocational training. Age groups are defined as 15-29 (young), 30-54 (middle-age) and 55-64 (old). We differentiate between full-time workers and a "non-standard" employment type category comprising both part-timers and irregular employment (short-term employment, temporary workers and those in marginal employment referred to as "Mini/Midijob" in Germany). We estimate input-output ratios separately for the five industries (manufacturing, construction, trade and communications, services and financial sector) which gives $5 \times 12=60$ different cells that can be used for the distributional analysis. There is clearly no complete congruence, and possibly a trade-off, between the definition of labor inputs used for the purpose of labor demand estimation on one hand, and a disaggregated cell definition for precise distributional analyses on the other. We feel that the choice made here presents a reasonable balance. In particular, skill and age/experience groups constitute different types of productive factors for firms 
but also correspond to groups exposed to different risks of unemployment or working-time adjustments during a labor-market downturn. One may wish more disaggregation for the distributional analysis (e.g., gender, migrants) but this would be more difficult to justify in terms of labor-input differentiation.

We specify our labor demand model with respect to total working hours exploiting establishment level working time information. To the best of our knowledge such a micro level hours specification is unique. Most of the related studies estimating demand systems rely on the textbook head-count specification. A few other papers specify their model in terms of hours by appending an hours-worked measure to the data (see Hamermesh (1993)). Due to a lack of firm-level information such working-hours measures normally rely on some sub-aggregate averages (in most cases on the industry level) at a given point in time (see Freier \& Steiner (2009) for a recent example). Our approach improves on this in several ways. First, we know actual full-time working hours, as well as the number of full-time and part-time workers, at the establishment level directly from LIAB. For full-time workers, we therefore have all the information needed for calculating total hours worked. For part-time workers, we exploit working-hours information at a disaggregated level from GSOEP. More specifically, we derive ratios of full-time and part-time working hours for each age/skill/employment type/industry/year cell in GSOEP. We then apply these ratios to the LIAB data to obtain part-time working hours. Using this approach, we construct a finely grained working hours distribution across worker groups in each establishment.

The model is estimated by adding disturbance terms $\varepsilon_{i}$ to the input-output ratios (2) for the $i=1, . ., 12$ inputs in each industry. The disturbance vector $\left\{\varepsilon_{1}, \ldots, \varepsilon_{12}\right\}$ is assumed to be multivariate and normally distributed with mean vector zero and constant covariance matrix $\Omega$. The system of 12 equations per industry is estimated using Seemingly Unrelated Regression (SUR) proposed by Zellner (1962). SUR first employs equation-by-equation OLS to obtain the covariance matrix of the error terms, $\Omega$, then a Feasible Generalized Least Squares estimation on the full system, conditional on $\Omega$ is conducted. Thus, SUR allows error terms to be contemporaneously correlated across regressions and is more efficient than separate OLS estimations.

Due to the complexity of the model and to save on space, we do not present the detailed estimates but simply focus on goodness-of-fit measures (and the predictive power of the model) and on output elasticities of labor demand, the important results for our purpose $^{4}$. Table 8 in the appendix presents standard goodness-of-fit measures by industry

\footnotetext{
${ }^{4}$ Detailed regression results are available from the authors on request.
} 
for all demand equations. The table shows that the model fit as indicated by the adjusted r-squared and chi-squared values is reasonably good, especially when taking into account that the equation system is quite complex and that 66 cross-equations constraints on the coefficients are imposed. ${ }^{5}$ Only the fit of the model for the financial sector is less than satisfactory, which is most probably due to challenges in measuring output in a manner consistent with other industries, as well as the relatively small number of observations. ${ }^{6}$

In addition, it is useful to check the predictive power of the model. In Figure 2, we plot yearly relative changes in total hours worked as reported in the LIAB data against changes as predicted by the model for each industry over 1996-2007. Predicted changes in working hours are derived by multiplying the industries' output elasticities by the industry-specific aggregate output change. With the exception of the financial sector, the graphs show that predictions appear quite accurate. This is reassuring regarding the estimated model and provides some confidence that using employment reaction to output changes over the entire period results in good approximations of employment changes in specific time periods.

Table 1 presents output elasticities of labor demand. For readability, we present average elasticities for broader input groups in this table. Complete results for all 60 cells are reported in Table 9 in the appendix. All group elasticities are positive as required by theory. The average output elasticity across all cells is 0.64 , which is well in line with other studies determining employment reactions to output shocks (normally output elasticities lie in [0.5, 0.9], see e.g. Brechling \& O'Brien (1967), Fay \& Medoff (1985) or Card (1986)). The results suggest that unskilled employees are hired more quickly in a boom and fired faster during a recession across all sectors. Output elasticities of young and, especially, older workers are also above average. As expected, those on non-standard employment contracts are more likely to be affected by output changes than regular ("full-time") employees.

\footnotetext{
${ }^{5}$ With $I=12$ simultaneous equations, the number of constraints following the condition $\alpha_{i j}=\alpha_{j i}$ is $\frac{I(I-1)}{{ }^{2}}=66$.

${ }^{2}$ In fact, we could not use any observations for the financial sector for the years 2006 and 2007 because the LIAB output measure changed as of 2006.
} 
Figure 2: Predictive power

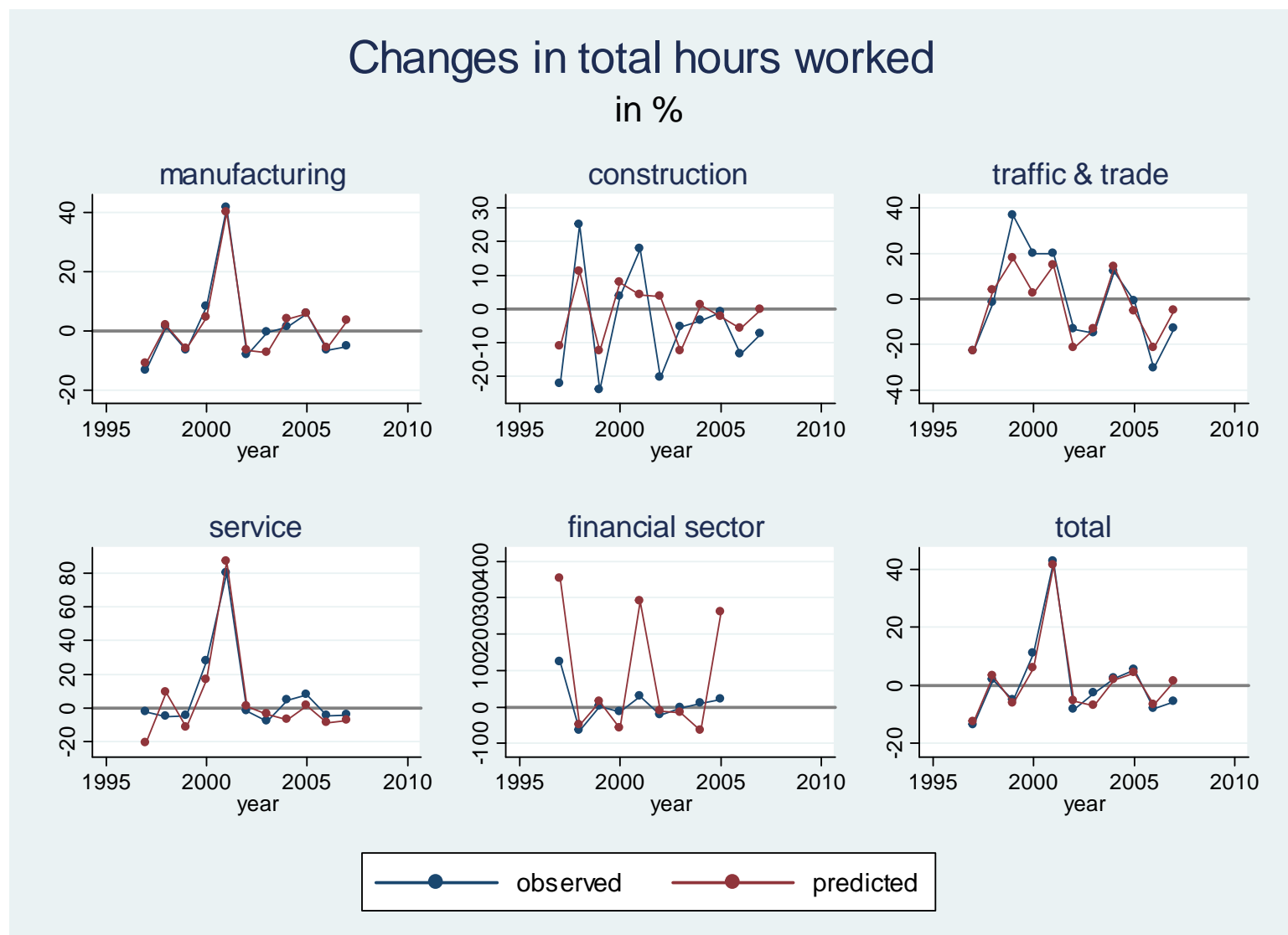

Note: Actual hours from LIAB, predicted hours calculated using LIAB output data and estimated elasticities.

Table 1: Output elasticities

\begin{tabular}{l|ccccc|c}
\hline \hline Group & Man & Con & Tra & Ser & Fin & Total \\
\hline Skilled & 0.57 & 0.45 & 0.79 & 0.62 & 0.94 & $\mathbf{0 . 5 9}$ \\
Unskilled & 1.05 & 0.5 & 1.02 & 0.99 & 1.02 & $\mathbf{0 . 9 6}$ \\
\hline Young & 0.74 & 0.55 & 0.02 & 0.72 & 0.87 & $\mathbf{0 . 6 8}$ \\
Middle-age & 0.62 & 0.41 & 0.92 & 0.61 & 0.96 & $\mathbf{0 . 6 1}$ \\
Old & 0.75 & 0.61 & 1.04 & 0.99 & 0.94 & $\mathbf{0 . 8 2}$ \\
\hline Full-time & 0.65 & 0.43 & 0.80 & 0.63 & 0.95 & $\mathbf{0 . 6 3}$ \\
Non-standard & 0.68 & 0.93 & 1.23 & 0.97 & 0.92 & $\mathbf{0 . 8 3}$ \\
\hline Total & $\mathbf{0 . 6 5}$ & $\mathbf{0 . 4 6}$ & $\mathbf{0 . 8 3}$ & $\mathbf{0 . 6 7}$ & $\mathbf{0 . 9 4}$ & $\mathbf{0 . 6 4}$ \\
\hline \hline
\end{tabular}

Source: Own calculations using LIAB. Notes: All numbers are averages weighted by the number of total hours in the respective cells. Man = Manufacturing, Con $=$ Construction, Tra = Transport and Communications, Ser $=$ Services, Fin $=$ Financial Services . 


\section{Employment and Distributional Effects}

We now model the impact of the crisis, first on employment using the labor demand model, then on household income distribution by transposing the predicted employment effects into the GSOEP data. Our reference period for the output shock (and subsequent employment/distributional changes) is the period 2008-2009, which corresponds to the recent downturn period in Germany.

\subsection{Output Shocks and Predicted Employment Effects}

Results are summarized in Table 2. The top panel reports changes in official output aggregates and employment by industry over the recent crisis period. Output, as measured by value added for each industry from German national accounts, dropped in all of the shown industries. Overall, the German economy shrunk by five percent over this period. In the selected sample of industries, value added declined by even more ( 8 percent). ${ }^{7}$ In particular, the decline in manufacturing output, a slump of 18 percent, is noteworthy.

Employment changes are shown in headcounts (employment levels) as well as total hours worked, accounting for adjustments along both the extensive and intensive margin. It is evident that the output shock did result in sizable labor demand effects overall. Yet, there is a considerable difference between the margins of adjustment. While changes in employment levels are minimal, total hours worked dropped substantially over a relatively short period of time, with a very large drop of about $10 \%$ in the manufacturing sector.

The bottom panel of Table 2 shows changes in total hours worked across industries and for different groups of workers as predicted by the labor demand model. For the prediction, we multiplied reported industry output changes with the corresponding output elasticities of labor demand in each of the 60 cells. As we have chosen a "total hours" specification, our predictions are conceptually comparable to the official changes in total working hours shown in the top part of the table. Our predictions capture the overall changes well, both quantitatively and qualitatively. Only in the Transport and Communications sector, we overestimate the labor demand reaction (possibly explained in part by stimulus spending benefiting this sector). Moreover, the table suggests that different types of workers are affected differently, with old, unskilled and non-standard workers suffering the most.

\footnotetext{
${ }^{7}$ The difference is mostly due to the public sector, where value added actually increased during the crisis period.
} 
Table 2: Output Shocks and Actual vs. Predicted Hours Adjustments

\begin{tabular}{|c|c|c|c|c|c|c|}
\hline & Man & Con & $\overline{\text { Tra }}$ & Ser & Fin & $\overline{\text { Total }}$ \\
\hline & \multicolumn{6}{|c|}{$\begin{array}{c}\text { Official statistics } \\
\text { Output (value added, price adjusted) }\end{array}$} \\
\hline 2008 & 496.4 & 78.8 & 130.5 & 949.6 & 76.1 & 1731.3 \\
\hline 2009 & 406.2 & 77.7 & 119.2 & 917.6 & 74.9 & 1595.6 \\
\hline \multirow[t]{2}{*}{$\%$ change } & -18 & -1 & -9 & -3 & -2 & -8 \\
\hline & \multicolumn{6}{|c|}{ Employment levels (in 1000 workers) } \\
\hline 2008 & 7352 & 1741 & 2079 & 12420 & 1045 & 24637 \\
\hline 2009 & 7163 & 1746 & 2067 & 12415 & 1042 & 24433 \\
\hline \multirow[t]{2}{*}{$\%$ change } & -3 & 0 & -1 & 0 & 0 & -1 \\
\hline & \multicolumn{6}{|c|}{ Total hours worked (in millions) } \\
\hline 2008 & 10383 & 2680 & 3015 & 15827 & 1483 & 33387 \\
\hline 2009 & 9352 & 2630 & 2915 & 15401 & 1457 & 31754 \\
\hline \multirow[t]{2}{*}{$\%$ change } & -10 & -2 & -3 & -3 & -2 & -5 \\
\hline & \multicolumn{6}{|c|}{$\begin{array}{l}\text { Predictions } \\
\text { urs worked }(\%\end{array}$} \\
\hline Total & -12 & -1 & -7 & -2 & -2 & -7 \\
\hline Skilled & -10 & -1 & -7 & -2 & -2 & -6 \\
\hline Unskilled & -19 & -1 & -9 & -3 & -2 & -11 \\
\hline Young & -14 & -1 & 0 & -2 & -1 & -8 \\
\hline Middle-age & -11 & -1 & -8 & -2 & -2 & -7 \\
\hline Old & -14 & -1 & -9 & -3 & -2 & -9 \\
\hline Full-time & -12 & -1 & -7 & -2 & -2 & -7 \\
\hline Non-standard & -12 & -1 & -11 & -3 & -1 & -8 \\
\hline
\end{tabular}

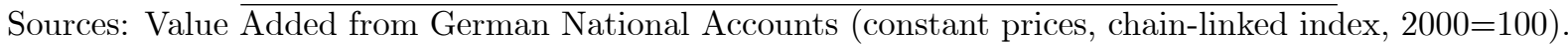
Official employment statistics from the Institute for Employment Research. Predictions are based on LIAB. Notes: Man $=$ Manufacturing, Con $=$ Construction, Tra $=$ Transport and Communications, Ser $=$ Services, Fin $=$ Financial Services .

\subsection{Cell Identification and Shock Scenarios}

We now feed the predicted employment shocks for each cell into the GSOEP, a representative micro dataset often used for distributional analyses. The GSOEP is informationally rich and allows us to differentiate by skill, age, employment group and industry, just as we did in the linked employer-employee data. Table 3 provides an overview of selected worker characteristics for both the LIAB and GSOEP datasets. The table reveals that, although general socio-demographic characteristics such as gender or nationality differ, the two datasets compare well as far as the dimensions of our cells are concerned. In particular, the age and employment-type distributions are almost identical.

The labor-demand model is specified in terms of total hours and hence accounts for 
Table 3: Worker characteristics, wave 2007

\begin{tabular}{lrr}
\hline \hline General & LIAB & GSOEP \\
\hline Observations (persons) & $1,828,126$ & 9,218 \\
Share of female & 38.3 & 44.4 \\
Share of foreigners & 5.4 & 16.0 \\
Share of working in East & 20.6 & 16.2 \\
& & \\
Skill distribution & & \\
\hline Share of skilled & 85.9 & 91.0 \\
Share of unskilled & 14.1 & 9.0
\end{tabular}

\begin{tabular}{lrr} 
Age distribution & & \\
\hline Share of young & 17.9 & 18.4 \\
Share of medium-aged & 67 & 68.2 \\
Share of old & 15.1 & 13.4 \\
Mean age & 41.8 & 41.6
\end{tabular}

Job distribution

\begin{tabular}{lcr}
\hline Share of full-timers & 73.4 & 72.9 \\
Share of part-timers & 26.6 & 27.1 \\
\hline \hline Source: Own calculations using LIAB and GSOEP.
\end{tabular}

adjustments at both the extensive and intensive margin. Yet, the model cannot predict which margin is used by a particular firm or sector. Thus, we must suggest concrete scenarios of labor market adjustments to translate total hour changes into income changes at the cell level. Since actual labor-input adjustments during the 2008-2009 crisis were mainly along the intensive margin in Germany, we suggest a first scenario where adjustments exclusively materialize as a change in worked hours (e.g., a switch from full-time to part-time employment). We simply change working hours proportionally in line with the total change in labor demand at the cell level, holding employment levels constant.

In a second polar case, we suggest a scenario where the same total hours adjustments only occur at the extensive margin through layoffs. That is, adjustments consist in changes in employment rates at the cell level: If the predicted change in labor demand for a given cell is $-X \%$, we randomly draw $X \%$ of workers within the GSOEP cell and make them unemployed. This second scenario corresponds more to the adjustment pattern that occurred in the United States.

We feel that these two scenarios provide interesting counterfactuals for the distributional and fiscal impact of the labor-market downturn which highlight the role of the adjustment margin in shaping distributional outcomes and correspond reasonably well to the adjustment patterns observed in Germany and the United States. It is likely, however, 
that the differences between the distributional effects of our stylised scenarios provide upper bound estimates. First, ajustments will generally take place along both the intensive and the extensive margins. On a more technical level, we abstract from the facts that working-hours reductions will not be uniform within each cell and that unemployment risks within cells will not be evenly distributed. However, in the context of our distributional analysis, the random draw will have no noticeable impact as cell definitions are already disaggregated. ${ }^{8}$

\subsection{Distributional and Fiscal Impacts}

The distributional analysis is based on GSOEP data before and after the two scenarios of labor-demand adjustment. We denote by "0" the pre-crisis (baseline) situation, by "1" the post-crisis scenario resulting from adjustments along the intensive margin only and by "2" the post-crisis scenario resulting from extensive-margin adjustments. Income distribution measures are based on household total income equivalized using the "modified OECD" scale. Capturing the household context (family size and composition) is of course a principal reason for performing the distributional analysis on GSOEP-type of data rather than using the worker-based LIAB directly.

We look at the distributions of both gross and net incomes in order to capture the cushioning effect of the tax-benefit system. We assume policy parameters as of January, 1st 2009. ${ }^{9}$ Table 4 shows large working-hours changes for workers in the manufacturing industry mirroring the predicted labor-input adjustments reported in Table $2 .{ }^{10}$ Gross earnings follow changes in total working hours. They are not the same, however, since working hours are shown at the individual level, whereas incomes are measured on an "equivalized" household basis and, hence, are also affected by the incomes of other family members. This is also why incomes can change for the non-employed and why relative

\footnotetext{
${ }^{8}$ For instance, in the case of the extensive scenario, any non-random modeling attempt would, in fact, run into difficulties as it would have to utilize characteristics (such as age, education) that are similar to the ones used to distinguish cells. Also note that some intermediary scenarios based on more realistic combinations of the intensive and extensive margins could be suggested but would require additional assumptions. We keep this work for future research.

${ }^{9}$ It is important to note that net income calculations do not account for benefits paid through the short-time working programme (Kurzarbeit) as our data do not allow us to identify the likely recipients of these benefits. This is relevant when considering the distributional effects reported for the "intensive" scenario below. While this provides a lower-bound for the incomes of many of the workers affected by reduced working hours, recall that the large majority of working-hour reductions in 2009 (75\%) were not on account of the Kurzarbeit system.

${ }^{10}$ Note that, because the sampling frames for the GSOEP and LIAB data are different and predictions from the demand model have been applied cell-by-cell to the GSOEP, total working-hours changes and by industry do not match exactly.
} 
changes in (household) earnings can exceed changes in (individual) working-hours reductions. Across industries, particularly unskilled workers are found to suffer the biggest earnings losses. Young individuals are also seeing large net income losses. Average losses are even larger than for the older age group, despite the earlier finding in Table 2 that older workers are somewhat more likely to face job loss or working-time reductions than young workers. One reason is that older workers are more likely to be living with a partner whose income partly shields them from a drop in household incomes.

It is striking that the net income effects are more sizable in the intensive scenario. This is because, in the intensive scenario, hours are equally reduced for everybody who is working in a specific cell. Hence, every worker in this cell suffers an equal, but relatively small income losses. Tax burdens also decline for these workers, which is why income losses are smaller on a net basis than before taxes. In the extensive scenario, certain workers are laid off, resulting in a sharp drop of their gross income. On top of reduced tax burdens, a considerable part of the earnings loss tends to be offset by an entitlement to unemployment benefits. Consequently, the income cushioning effect of the tax-benefit system is larger than under the intensive scenario, and the difference between net and gross income changes is more sizable as a result. Note that this effects also operates for non-employed individuals, who can be sharing a household with job losers entitled to unemployment benefits.

Comparing changes in gross and net income gives some indication of the effectiveness of social safety nets at absorbing some of the income loss. The income of low-skilled workers is likely to be relatively close to the level of minimum-income benefits. Safety-net benefits therefore absorb a large part of their earnings losses on average resulting in large differences between gross and net earnings changes. Reflecting the EUR 400/800 ceiling on monthly earnings in the German Mini/Midijob programme, wages of many workers in the "non-standard" category are also especially low. However, these jobs are particularly attractive for second earners. Because of their higher-earning partners, they are then less likely to receive means-tested benefits when losing all or part of their own earnings.

Table 5 presents changes of incomes and working hours by decile groups. ${ }^{11}$ Interestingly, relative net income losses in the "intensive" scenario are very similar from decile four to ten. Perhaps even more strikingly, the lowest two decile groups see the smallest net income changes, showing the effectiveness of the benefit system. A somewhat similar picture emerges if labor demand adjustments take place entirely through layoffs. Again, net income losses tend to be less severe than in the intensive scenario. This is not the case, however, for the first two decile groups. The reason is that those at the bottom of

\footnotetext{
${ }^{11}$ Table 10 in the appendix shows the same information in absolute values
} 
Table 4: Relative change in earnings and hours for working-age individuals and family members (by group, in \%)

\begin{tabular}{l|cccccc}
\hline \hline & \multicolumn{3}{|c}{ Intensive } & \multicolumn{3}{c}{ Extensive } \\
& Gross & Net & Hours & Gross & Net & Hours \\
\hline Skilled & -3.6 & -2.4 & -3.3 & -3.6 & -2.2 & -3.3 \\
Unskilled & -6.6 & -3.4 & -6.3 & -6.6 & -2.7 & -6.3 \\
\hline Young & -3.6 & -2.7 & -3.6 & -3.6 & -2.4 & -3.6 \\
Middle-age & -3.8 & -2.2 & -3.0 & -3.9 & -2.0 & -3.1 \\
Old & -3.5 & -1.8 & -3.3 & -3.6 & -1.7 & -3.4 \\
\hline Full-time & -3.6 & -2.6 & -3.4 & -3.6 & -2.3 & -3.4 \\
Non-standard & -4.7 & -2.7 & -4.6 & -4.7 & -2.4 & -4.6 \\
Non-employed & -4.3 & -1.7 &. & -4.2 & -1.2 &. \\
\hline Manufacturing & -9.4 & -7.0 & -11.2 & -9.2 & -6.2 & -11.2 \\
Construction & -1.3 & -0.9 & -0.7 & -1.3 & -0.8 & -0.8 \\
Transport-Comm & -6.3 & -4.2 & -7.0 & -6.4 & -3.8 & -7.1 \\
Services & -2.8 & -1.8 & -2.2 & -3.0 & -1.8 & -2.3 \\
Financial & -2.4 & -1.8 & -1.5 & -2.4 & -1.5 & -1.5 \\
\hline Total & $\mathbf{- 3 . 7}$ & $\mathbf{- 2 . 5}$ & $\mathbf{- 3 . 5}$ & $\mathbf{- 3 . 7}$ & $\mathbf{- 2 . 2}$ & $\mathbf{- 3 . 5}$ \\
\hline \hline
\end{tabular}

Source: Own calculations using GSOEP and IZA $\overline{\bar{n} \text { MOD. Note: Incomes are equivalized }}$ (modified OECD scale), working hours are shown on an individual basis.

the income distribution tend to be entitled to means-tested benefits, which ensure that net incomes at the very bottom change very little in both the intensive and extensive scenarios. As a result, whether or not those affected by earnings losses are entitled to unemployment benefits makes little difference and net income changes for the two scenarios are more similar for the bottom two deciles than for middle-class households.

Table 6 reports a range of global distribution measures (Gini, General Entropy, interdecile ratio), as well as absolute and relative poverty headcount (Foster-Greer-Thorbecke: FGT0) and poverty intensity (FGT1, FGT2). Consistent with the results by income deciles, overall inequality is reduced in the "intensive" scenario. The income distribution is compressed as parts of the working population suffer income losses, while the net incomes of the non-employed change less. In the "extensive" scenario, however, inequality rises as some workers are laid off while others are not affected by the crisis at all. Because the incidence of job losses is particularly high for some groups who tend to have low incomes even prior to unemployment (e.g., young and low-skilled workers), this additional unemployment yields a further dispersion of the income distribution. The difference between the inequality measures in the two scenarios illustrates that facilitating working-hours adjustments can play an important role in limiting the growth of income disparities during a downturn. 
Table 5: Relative change in earnings and hours by income decile (in \%)

\begin{tabular}{l|cccccc}
\hline \hline & \multicolumn{3}{|c}{ Intensive } & \multicolumn{3}{c}{ Extensive } \\
& Gross & Net & Hours & Gross & Net & Hours \\
\hline 1 & -3.7 & -0.3 & -3.2 & -4.1 & -0.6 & -3.1 \\
2 & -3.8 & -0.6 & -3.8 & -3.8 & -0.7 & -3.7 \\
3 & -3.9 & -2.0 & -3.8 & -3.7 & -1.2 & -3.6 \\
4 & -3.8 & -2.7 & -3.5 & -3.7 & -1.7 & -3.5 \\
5 & -3.8 & -2.9 & -3.5 & -4.0 & -2.2 & -3.7 \\
6 & -4.3 & -3.0 & -3.9 & -4.2 & -2.5 & -3.8 \\
7 & -3.6 & -2.6 & -3.5 & -3.7 & -2.5 & -3.7 \\
8 & -3.7 & -2.8 & -3.4 & -3.6 & -2.6 & -3.4 \\
9 & -3.4 & -2.5 & -3.1 & -3.2 & -2.3 & -3.1 \\
10 & -3.8 & -2.5 & -3.3 & -3.9 & -2.5 & -3.4 \\
\hline Total & $\mathbf{- 3 . 7}$ & $\mathbf{- 2 . 5}$ & $\mathbf{- 3 . 5}$ & $\mathbf{- 3 . 7}$ & $\mathbf{- 2 . 2}$ & $\mathbf{- 3 . 5}$ \\
\hline
\end{tabular}

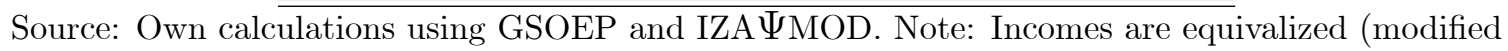
OECD scale), working hours are shown on an individual basis. Decile groups are for the selected sample only (working-age individuals and household members) and are based on the "pre-crisis" baseline.

This can also be seen when looking at poverty measures. In the intensive scenario, the share of the poor as indicated by the headcount ratio using a constant poverty line (FGT0) increases only slightly, while we see a substantial rise of more than ten percent in the extensive case. Other poverty indicators come to quantitatively similar results. But interestingly, with a variable poverty line (FGT0v), the number of poor in the intensive scenario actually goes down, since median income (and, hence, the poverty threshold) drop more strongly than incomes at the very bottom of the distribution. These results underline the importance of evaluating relative poverty measures alongside absolute changes in income levels, especially when assessing the distributional consequences of rapid economic change.

Finally, we shed some light on the role of the margin of adjustment for government budgets. Table 7 shows the fiscal effects of the two scenarios relative to the baseline case, i.e. the German tax benefit system as of January, 1st 2009 without any crisis-related employment changes. As one would expect, both scenarios result in a highly negative effect on the government budget. Tax revenue and social insurance contributions (SIC) decrease as labor earnings drop for those employees affected by the crisis. It is interesting to note the differences between the two scenarios in terms of taxes and SIC. In the intensive case, the proportional reduction in combination with the progressive income taxation and regressive SIC yields higher relative tax revenue reductions. In the extensive scenario, employment reductions are highest in the middle part of the income distribution (cf. Table 5), where SIC payments are higher than tax liabilities. As the highly progressive 
Table 6: Inequality and poverty measures and relative change

\begin{tabular}{l|ccccc}
\hline \hline & \multicolumn{2}{|c}{ Base } & \multicolumn{2}{|c}{ Intensive } & \multicolumn{2}{c}{ Extensive } \\
& Net & Net & $\Delta($ in $\%)$ & Net & $\Delta($ in\%) \\
\hline Gini & 0.324 & 0.323 & -0.385 & 0.330 & 1.637 \\
GE0 & 0.176 & 0.174 & -1.193 & 0.181 & 2.972 \\
GE1 & 0.197 & 0.197 & -0.161 & 0.203 & 3.079 \\
P9010 & 4.251 & 4.175 & -1.807 & 4.307 & 1.304 \\
FGT0 & 0.205 & 0.213 & 3.588 & 0.229 & 11.653 \\
FGT1 & 0.048 & 0.050 & 2.142 & 0.054 & 12.388 \\
FGT2 & 0.019 & 0.020 & 4.289 & 0.023 & 19.085 \\
FGT0v & 0.205 & 0.195 & -5.067 & 0.214 & 4.516 \\
\hline \hline
\end{tabular}

Source: Own calculations using GSOEP and IZA $\Psi$ MOD. Notes: Measures are based on equivalized disposable incomes (modified OECD scale) and refer to the selected sample only (working-age individuals and household members). The poverty line is set at $60 \%$ of median income (of the total population) and is either constant using the baseline median (FGT0, FGT1, FGT2), or variable using the median of each scenario (FGT0v).

Table 7: Fiscal effect

\begin{tabular}{l|cc|cc}
\hline \hline & \multicolumn{2}{|c|}{ Intensive } & \multicolumn{2}{c}{ Extensive } \\
Changes & in billion euros & in \% & in billion euros & in \% \\
\hline Tax revenue & -5.6 & -4.2 & -3.0 & -2.3 \\
Social insurance contributions & -5.4 & -3.2 & -6.3 & -3.8 \\
Benefit payments & -1.0 & 1.1 & -5.3 & 5.9 \\
\hline Total budget effect & -11.9 & -5.7 & -14.6 & -7.0 \\
\hline \hline
\end{tabular}

Source: Own calculations using GSOEP and IZA $\Psi$ MOD. Notes: percentage changes refer to each category (ex: tax revenue goes down by $4.2 \%$ in intensive scenario)

German income tax is concentrated at the top (with the top ten percent paying more than 55 percent of the income tax revenue), the reduction in tax revenue is relatively lower than the decrease in SIC. Due to higher benefit expenditures, the fiscal consequences of the extensive scenario are, however, substantially more severe (benefit payments increase by $6 \%$ ). In total, the government's budget is decreasing by 7 percent in this case. This yields an eventual shortfall which is approximately 3 billion euros higher than in the intensive scenario, given our considered population sample. ${ }^{12}$

\footnotetext{
${ }^{12}$ In a back-of-the-envelope calculation one could argue that the German short-term working scheme, Kurzarbeit, was an efficient investment for the initial phase of the crisis - costing a similar amount (3 billion euros per year), encouraging reductions in total working hours and thus keeping many employees in the workforce.
} 


\section{Conclusion}

In this paper we propose a new method to gauge the first-round labor-market, distributional and fiscal implications of large output changes. The method is based on a disaggregated labor-demand model motivated by the fact that labor demand changes are the principal driving factor of household income losses in the early phase of a labor-market downturn. The labor-demand adjustments are then combined with detailed household microdata to translate changes in individual earnings into income changes at the household level. This approach can help policymakers to design policy responses to economic downturns in the absence of reliable real-time microdata.

We apply the method to investigate the impact of the 2008-2009 downturn in Germany. Our results show that German low-skilled and non-standard workers faced above-average risks of earnings losses, in particular if they worked in the manufacturing sector where output reductions were very large. When looking at the resulting income losses, it turns out, however, that automatic stabilization by the tax-benefit system is effective in cushioning a significant share of the gross-income losses, especially among low-income groups (cf. also Dolls et al. (2010)).

The choice of Germany is interesting as German employment levels and unemployment rates were unusually stable in the face of a large and rapid drop in economic output, while average hours worked per employee did decline significantly. This reflects in part Germany's primary policy response to the crisis facilitating necessary labor-cost adjustments via working-hours reductions rather than layoffs. To shed light on the role of different margins of adjustment on distributional and fiscal implications of the downturn, our first scenario assumes that all employment adjustments take place via such working-hour reductions. As a contrasting scenario, we have also explored a polar situation closer to the US experience, where adjustments of employment levels were far greater. Our results show that, while a strategy to promote working-hour adjustments through work-sharing and other measures cannot prevent significant income losses, it can be highly effective at avoiding very large increases in income poverty. Calculations for Germany also show that intensive-margin adjustments are less costly for the government budget.

Our empirical approach has several limitations which are left for further research. Our estimates do not explicitly account for the German short-term working scheme. While participation in the scheme has been shown to be costly for firms (Bach \& Spitznagel (2009)), it is likely that, as a de facto subsidy to firms, it played a role in firms' decisions on the margin of adjustment. ${ }^{13}$ Secondly and more generally, the approach in this paper

\footnotetext{
${ }^{13}$ In particular, measures such as the Kurzarbeitergeld, which protect existing jobs, tend to reinforce
} 
has utilized recent historical data to make inferences about the effects of the current labormarket downturn. The demand model provides an interesting "average" approximation of short-term effects of output shocks. Yet institutional changes over recent years may have affected the demand for different groups of workers in complicated ways, and the policies put in place during the crisis had their own specific effects. Hence an important but challenging improvement would consist in explicitly modeling policy institutions in the labor demand estimation. Finally, an obvious limitation is the short-term horizon adopted here going along with the assumption of constant wage levels as well as the usual constant-capital assumption in labor-demand models. Although it would be worthwhile to model wage variations by interacting labor demand and supply iteratively in order to attain equilibrium (see e.g. Peichl \& Siegloch (2010)), we have argued that this assumption is not too restrictive in the context of our study as wage reductions were not a primary response to the labor-market downturn in Germany.

employer incentives to hoard highly educated or experienced workers, while less attractive jobs may be cut more quickly. It is therefore possible that their distributional properties are less attractive than the stylized across-the-board working-time reductions considered in this paper, especially if they reduce labor-market dynamics, making labor-market re-entry more difficult for laid-off workers. It would be interesting to investigate the incidence of short-time working schemes more closely once the required data become available. 


\section{A Appendix}

Table 8: R-Squared Chi-Squared values of Demand Equations by Industry

\begin{tabular}{|c|c|c|c|c|c|c|c|c|c|c|}
\hline \multirow[b]{2}{*}{ Demand Eq } & \multicolumn{2}{|c|}{ Man } & \multicolumn{2}{|c|}{ Con } & \multicolumn{2}{|c|}{ Tra } & \multicolumn{2}{|c|}{ Ser } & \multicolumn{2}{|c|}{ Fin } \\
\hline & adj-R2 & chi2 & adj-R2 & chi2 & adj-R2 & chi2 & adj-R2 & chi2 & adj-R2 & chi2 \\
\hline $\mathrm{Sk} / \mathrm{You} / \mathrm{FT}$ & 0.39 & 11566 & 0.39 & 3275 & 0.43 & 1461 & 0.97 & 314545 & 0.29 & 269 \\
\hline $\mathrm{Sk} / \mathrm{You} / \mathrm{PT}$ & 0.22 & 4334 & 0.14 & 937 & 0.08 & 129 & 0.09 & 854 & 0.65 & 996 \\
\hline $\mathrm{Sk} / \mathrm{Mid} / \mathrm{FT}$ & 0.15 & 4704 & 0.37 & 3808 & 0.07 & 548 & 0.92 & 125166 & 0.07 & 54 \\
\hline $\mathrm{Sk} / \mathrm{Mid} / \mathrm{PT}$ & 0.22 & 5530 & 0.24 & 1808 & 0.32 & 869 & 0.05 & 612 & 0.03 & 42 \\
\hline $\mathrm{Sk} / \mathrm{Old} / \mathrm{FT}$ & 0.09 & 2526 & 0.28 & 2103 & 0.06 & 289 & 0.02 & 773 & 0.04 & 43 \\
\hline $\mathrm{Sk} / \mathrm{Old} / \mathrm{PT}$ & 0.29 & 7003 & 0.32 & 2310 & 0.11 & 165 & 0.05 & 738 & -0.02 & 8 \\
\hline USk/You/FT & 0.11 & 2323 & 0.18 & 1149 & 0.20 & 448 & 0.03 & 635 & -0.01 & 12 \\
\hline USk/You/PT & 0.44 & 14518 & 0.33 & 2521 & 0.16 & 296 & 0.08 & 875 & 0.03 & 16 \\
\hline USk/Mid/FT & 0.11 & 2589 & 0.27 & 1784 & 0.28 & 822 & 0.06 & 1214 & 0.04 & 27 \\
\hline USk/Mid/PT & 0.12 & 1676 & 0.17 & 537 & 0.26 & 609 & 0.07 & 520 & -0.01 & 7 \\
\hline USk/Old/FT & 0.11 & 1317 & 0.19 & 1110 & 0.15 & 370 & 0.09 & 908 & 0.01 & 10 \\
\hline USk/Old/PT & 0.09 & 1308 & 0.11 & 561 & 0.25 & 316 & 0.09 & 697 & 0.11 & 13 \\
\hline Observations & \multicolumn{2}{|c|}{19520} & \multicolumn{2}{|c|}{5035} & \multicolumn{2}{|c|}{1847} & \multicolumn{2}{|c|}{10956} & \multicolumn{2}{|c|}{600} \\
\hline Parameters & \multicolumn{2}{|c|}{23} & \multicolumn{2}{|c|}{23} & \multicolumn{2}{|c|}{23} & \multicolumn{2}{|c|}{23} & \multicolumn{2}{|c|}{21} \\
\hline
\end{tabular}

Source: Own calculations using LIAB. Notes: Number of observations and parameters are the same for each equation within a sector. Man = Manufacturing, Con = Construction, Tra = Transport and Communications, Ser $=$ Services, Fin $=$ Financial Services. $(U)$ Sk $=(U n)$ skilled, You=Young, Mid $=$ Middle-age, $\mathrm{FT}=$ full-time, $\mathrm{PT}=$ Part-timer and irregular employees. 
Table 9: Output elasticities per cell

\begin{tabular}{l|ccccc}
\hline \hline Cell values & Man & Con & Tra & Ser & Fin \\
\hline $\mathrm{Sk} /$ You/FT & 0.67 & 0.42 & -0.09 & 0.63 & 0.88 \\
$\mathrm{Sk} /$ You/PT & 0.96 & -0.29 & 0.78 & 0.94 & 0.76 \\
$\mathrm{Sk} / \mathrm{Mid} / \mathrm{FT}$ & 0.53 & 0.45 & 0.85 & 0.52 & 0.96 \\
$\mathrm{Sk} / \mathrm{Mid} / \mathrm{PT}$ & 0.50 & 2.10 & 1.21 & 0.97 & 0.95 \\
$\mathrm{Sk} / \mathrm{Old} / \mathrm{FT}$ & 0.77 & 0.40 & 0.99 & 0.98 & 0.93 \\
$\mathrm{Sk} / \mathrm{Old} / \mathrm{PT}$ & 0.62 & 0.29 & 2.22 & 1.00 & 0.97 \\
$\mathrm{USk} / \mathrm{You} / \mathrm{FT}$ & 0.95 & 1.17 & -0.20 & 0.99 & 1.10 \\
$\mathrm{USk} /$ You/PT & 0.99 & 0.89 & 0.95 & 0.96 & 0.95 \\
$\mathrm{USk} / \mathrm{Mid} / \mathrm{FT}$ & 1.15 & -0.35 & 1.30 & 0.99 & 1.04 \\
$\mathrm{USk} / \mathrm{Mid} / \mathrm{PT}$ & 0.41 & -0.32 & 1.26 & 0.99 & 1.00 \\
$\mathrm{USk} / \mathrm{Old} / \mathrm{FT}$ & 0.89 & 3.09 & 0.74 & 1.04 & 1.00 \\
$\mathrm{USk} / \mathrm{Old} / \mathrm{PT}$ & 0.25 & 0.36 & -0.33 & 0.99 & 0.96 \\
\hline \hline
\end{tabular}

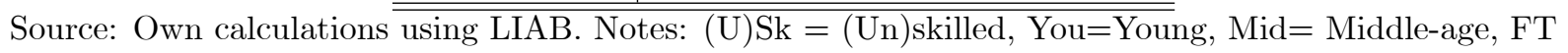
$=$ full-time, $\mathrm{PT}=$ Part-timer and irregular employees.

Table 10: Earnings and hours by income deciles

\begin{tabular}{l|ccccccccc}
\hline \hline & \multicolumn{4}{|c}{ Base } & \multicolumn{4}{c}{ Intensive } & \multicolumn{3}{c}{ Extensive } \\
& Gross & Net & Hours & Gross & Net & Hours & Gross & Net & Hours \\
\hline 1 & 161.4 & 643.5 & 10.1 & 155.5 & 641.4 & 9.8 & 154.9 & 639.9 & 9.8 \\
2 & 494.6 & 896.5 & 21.5 & 475.9 & 891.5 & 20.7 & 475.7 & 890.0 & 20.7 \\
3 & $1,027.6$ & $1,119.4$ & 29.0 & 987.3 & $1,096.9$ & 27.9 & 989.4 & $1,105.8$ & 27.9 \\
4 & $1,376.5$ & $1,357.1$ & 29.9 & $1,324.3$ & $1,320.8$ & 28.8 & $1,326.2$ & $1,334.6$ & 28.9 \\
5 & $1,715.0$ & $1,580.1$ & 32.1 & $1,650.0$ & $1,534.6$ & 31.0 & $1,646.5$ & $1,545.3$ & 30.9 \\
6 & $1,945.8$ & $1,810.6$ & 33.1 & $1,863.0$ & $1,755.6$ & 31.8 & $1,864.7$ & $1,765.4$ & 31.8 \\
7 & $2,379.2$ & $2,091.5$ & 35.9 & $2,293.2$ & $2,036.2$ & 34.6 & $2,290.4$ & $2,038.2$ & 34.5 \\
8 & $2,726.9$ & $2,416.2$ & 35.6 & $2,626.8$ & $2,348.2$ & 34.4 & $2,628.5$ & $2,353.6$ & 34.4 \\
9 & $3,289.1$ & $2,948.2$ & 36.7 & $3,178.6$ & $2,873.7$ & 35.6 & $3,185.1$ & $2,879.7$ & 35.6 \\
10 & $4,679.4$ & $5,107.6$ & 38.5 & $4,503.6$ & $4,979.9$ & 37.3 & $4,495.0$ & $4,980.1$ & 37.2 \\
\hline Total & $1,978.4$ & $1,995.5$ & 30.2 & $1,904.7$ & $1,946.4$ & 29.2 & $1,904.5$ & $1,951.8$ & 29.2 \\
\hline
\end{tabular}

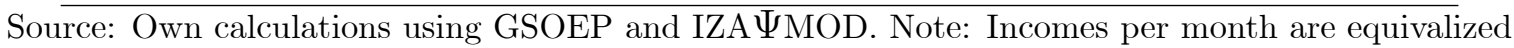
(modified OECD scale), hours are per week. 


\section{References}

Ahmed, V. \& O’Donoghue, C. (2010). Global Economic Crisis and Poverty in Pakistan, International Journal of Microsimulation 3(1): 127-129.

Alda, H., Bender, S. \& Gartner, H. (2005). The Linked Employer-Employee Dataset of the IAB (LIAB), Schmollers Jahrbuch - Journal of Applied Social Science Studies 125(2): $327-336$.

Bach, H.-U. \& Spitznagel, E. (2009). Betriebe zahlen mit - und haben was davon, IAB Kurzbericht No. 17.

Bellmann, L., Gerlach, K. \& Meyer, W. (2008). Company-Level Pacts for Employment, Journal of Economics and Statistics 228(4): 533-553.

Bellmann, L. \& Gerner, H.-D. (2010). Reversed Roles? Wage and Employment Effects of the Current Crisis, IAB Working Paper.

Bender, S., Haas, A. \& Klose, C. (2000). The IAB Employment Subsample 1975-1995, Schmollers Jahrbuch - Journal of Applied Social Science Studies 120(4): 649-662.

Bond, S. \& Van Reenen, J. (2007). Microeconometric Models of Investment and Employment, in J. J. Heckman \& E. Leamer (eds), Handbook of Econometrics, Vol. 6, Elsevier, chapter 65 .

Bourguignon, F., Bussolo, M. \& da Silva, L. P. (2008). The impact of macro-economic policies on poverty and income distribution Ü Macro-Micro Evaluation Techniques and Tools, Palgrave-Macmillan, New York.

Bourguignon, F., Robilliard, A.-S. \& Robinson, S. (2003). Representative versus Real Households in the Macro-Economic Modelling of Inequality, DIAL Document de Travail DT/2003-10.

Brechling, F. \& O'Brien, P. (1967). Short-Run Employment Functions in Manufacturing Industries: An International Comparison, The Review of Economics and Statistics 49(3): $277-287$.

Bresson, G., Kramarz, F. \& Sevestre, P. (1992). Heterogeneous Labor and the Dynamics of Aggregate Labor Demand: Some Estimations Using Panel Data, Empirical Economics 17(1): 153-168.

Card, D. (1986). Efficient Contracts with Costly Adjustment: Short-Run Employment Determination for Airline Mechanics, Amercian Economic Review 76(5): 1045-1071. 
Collective Agreement Archive (2009). Tarifpolitik 2009 auf einen Blick, Informationen zur Tarifpolitik, Wirtschafts- und Sozialwissenschaftliches Institut der Hans-BöcklerStiftung (WSI).

URL: www.tarifvertrag.de

Diewert, W. E. (1971). An Application of the Shephard Duality Theorem: A Generalized Linear Production Function, Journal of Political Economy 79(3): 481-507.

Diewert, W. E. \& Wales, T. J. (1987). Flexible Functional Forms and Global Curvature Conditions, Econometrica 55(1): 43-68.

Dolls, M., Fuest, C. \& Peichl, A. (2010). Automatic Stabilizers and Economic Crisis: US vs. Europe, NBER Working Paper 16275.

Eichhorst, W., Feil, M. \& Marx, P. (2010). Crisis? What Crisis? Patterns of Adaptation in European Labor Markets, Applied Economics Quarterly Supplement 56(61): 29-64.

Fay, J. A. \& Medoff, J. L. (1985). Labor and Output Over the Business Cycle: Some Direct Evidence, Amercian Economic Review 75(4): 638-655.

Ferreira, F. H. G., Leite, P. G., Pereira da Silva, L. A. \& Picchettib, P. (2008). Can the Distributional Impacts of Macroeconomic Shocks Be Predicted? A Comparison on Top-Down Macro-Micro Models with Historical Data for Brazil, in F. Bourguignon, L. A. Pereira da Silva \& M. Bussolo (eds), The Impact of Macroeconomic Policies on Poverty and Income Distribution: Macro-Micro Evaluation Techniques and Tools, Palgrave Macmillan, Washington, DC, p. 119 Ü175.

Freier, R. \& Steiner, V. (2009). 'Marginal employment' and the demand for heterogeneous labour - elasticity estimates from a multi-factor labour demand model for Germany, Applied Economics Letters pp. 1-6.

Gupta, A. \& Kapur, V. (2000). Microsimulation in Government Policy and Forecasting, North-Holland, Amsterdam.

Hamermesh, D. S. (1986). The Demand for Labor in the Long Run, in O. Ashenfelter \& R. Layard (eds), Handbook of Labor Economics, Vol. 1, Elsevier B.V., Amsterdam, pp. 429-471.

Hamermesh, D. S. (1993). Labor Demand, Princeton University Press, Princeton.

Herault, N. (2010). Sequential Linking of Computable General Equilibrium and Microsimulation Models: A Comparison of Behavioural and Reweighting Techniques, International Journal of Microsimulation 3(1): 35-42. 
Kölling, A. (2000). The IAB-Establishment Panel, Schmollers Jahrbuch - Journal of Applied Social Science Studies 120(2): 291-300.

Möller, J. (2010). The German labor market response in the world recession : demystifying a miracle, Journal for Labour Market Research 42(4): 325-336.

OECD (2010). Moving beyond the Jobs Crisis, in OECD (ed.), Employment Outlook, OECD, Paris, pp. 15-102.

Peichl, A. (2009). The Benefits and Problems of Linking Micro and Macro Models: Evidence from a Flat Tax Analysis for Germany, Journal of Applied Economics 12(2): 301-329.

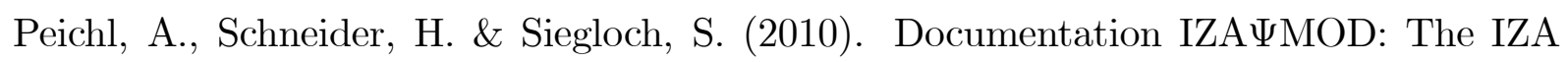
Policy SImulation MODel, IZA Discussion Paper No. 4865.

Peichl, A. \& Siegloch, S. (2010). Accounting for labor demand effects in structural labor supply models. IZA Discussion Paper.

Robilliard, A.-S., Bourguignon, F. \& Robinson, S. (2008). Examining the CSocial Impact of the Crisis Using a Macro-Micro Modeling Framework, in F. Bourguignon, L. A. Pereira da Silva \& M. Bussolo (eds), The Impact of Macroeconomic Policies on Poverty and Income Distribution: Macro-Micro Evaluation Techniques and Tools, Palgrave Macmillan, Washington, DC, pp. 93-118.

von Wachter, T. \& Bender, S. (2006). In the Right Place at the Wrong Time: The Role of Firms and Luck in Young Workers' Careers, American Economic Review 96(5): 1679-1705.

Wagner, G. G., Frick, J. R. \& Schupp, J. (2007). The German Socio-Economic Panel (SOEP) - Scope, Evolution and Enhancements, Schmoller's Jahrbuch - Journal of Applied Social Science Studies 127(1): 139-169.

Zellner, A. (1962). An Efficient Method of Estimating Seemingly Unrelated Regressions and Tests of Aggregation Bias, Journal of the American Statistical Association $\mathbf{5 7}(2)$ : $348-368$. 